\title{
Five configurations of opportunism in international market entry
}

Article

Accepted Version

Verbeke, A., Ciravegna, L., Lopez, L. E. and Kundu, S. K. (2019) Five configurations of opportunism in international market entry. Journal of Management Studies, 56 (7). pp. 1287-1313. ISSN 1467-6486 doi: https://doi.org/10.1111/joms.12355 Available at https://centaur.reading.ac.uk/78322/

It is advisable to refer to the publisher's version if you intend to cite from the work. See Guidance on citing.

To link to this article DOI: http://dx.doi.org/10.1111/joms.12355

Publisher: Wiley-Blackwell

All outputs in CentAUR are protected by Intellectual Property Rights law, including copyright law. Copyright and IPR is retained by the creators or other copyright holders. Terms and conditions for use of this material are defined in the End User Agreement.

\section{www.reading.ac.uk/centaur}

\section{CentAUR}

Central Archive at the University of Reading 
Reading's research outputs online 
Five Configurations of Opportunism in International Market Entry ${ }^{1}$

\author{
Alain Verbeke \\ Haskayne School of Business \\ University of Calgary \\ 2500 University Dr. NW \\ Calgary, Alberta, Canada \\ $\mathrm{T} 2 \mathrm{~N} 1 \mathrm{~N} 4$ \\ alain.verbeke@haskayne.ucalgary.ca
}

Henley Business School, University of Reading (UK)

\author{
Luciano Ciravegna \\ King's College, University of London \\ Bush House, NE Wing \\ London, WC2B 4BG \\ And \\ INCAE Business School, Costa Rica \\ luciano.ciravegna@kcl.ac.uk \\ Luis E. Lopez \\ INCAE Business School \\ Apartado 960-4050 \\ Alajuela, Costa Rica \\ Luis.Lopez@incae.edu \\ Sumit K. Kundu \\ College of Business \\ Florida International University \\ 448 MANGO Building \\ 11200 SW 8 Street \\ Miami, FL 33199, USA \\ kundus@fiu.edu
}




\title{
Five Configurations of Opportunism in International Market Entry
}

\begin{abstract}
We investigate the conditions under which opportunism occurs in international market entry. Examining 133 entries into new markets by 38 Chinese exporters, we uncover instances of opportunistic behaviour on the part of importers. We study five variables affecting such behaviour: managerial experience, market entry share, market distance, young age, and network size. While we find no single variable on its own associated with opportunism, we do find that in concert they form five configurations of opportunism. In one configuration, even older firms with experienced managers and a large network are subject to partners behaving opportunistically when they are entering a distant market. We conclude that simplistic predictions based on the presence of a single antecedent should make way for a configurational approach whereby a set of conditions must be in place for opportunism to materialize.
\end{abstract}

Keywords: Internalization theory, internationalization, market entry, opportunism, transaction cost economics 


\section{INTRODUCTION}

Entering a foreign market is risky and can affect a firm's long-term evolution (Markman and Waldron, 2014). Much influential international business (IB) research draws upon transaction cost economics (TCE) to describe the challenges of internationalizing (for classic references, see Buckley and Casson, 1998, 2009; Hennart, 1982, 1988, 2009; Rugman and Verbeke, 2003; for a recent synthesis, see Buckley, 2016). Opportunism, which Williamson (1985, p. 30) defines as 'self-interest seeking behavior with guile', poses threats to successful international market entry. Firms can adopt a variety of governance mechanisms to mitigate these threats (Narula and Verbeke, 2015; Williamson, 1985).

A large segment of the predictive scholarly work on entry mode choice builds upon the assumption of opportunism, that is, a tendency toward deceitful behaviour leading to explicit or implicit violations of contracts with foreign partners. Yet, few IB studies have actually examined the conditions under which opportunism occurs leaving an important gap between theory, where opportunism is a key assumption, and empirics, where evidence continues to be scarce (Kano and Verbeke, 2015). One reason for the gap is that mainstream IB theory purports to be predictive, meaning that firms are assumed to select 'optimal' entry modes, i.e. those that minimize opportunism. Thus, by design, the empirical IB literature does not examine the contexts wherein opportunism actually occurs, because it focuses on how to avoid it (Brouthers, 2002; Verbeke and Ciravegna, 2018).

We address the gap and respond to calls for more research on opportunism in new market entries (Luo, 2007a; Verbeke and Greidanus, 2009). Our focus is on how managers actually make decisions as opposed to how they should be making them (Buckley et al., 2007). In international 
market entries, both parties involved, the firms entering a host country--exporters for example-and their host country partners--the corresponding importers--can act opportunistically and thus inflict costs on each other. In this paper, we address the following research question: When exporters enter new, foreign markets, which combinations of antecedents will be associated with importers' opportunism?

We look at 133 international entries by 38 textile exporters from China into 41 foreign markets, using fuzzy sets Qualitative Comparative Analysis - fsQCA (Misangyi et al., 2017). ${ }^{2}$ We analyze five antecedents of opportunism derived from mainstream IB research (Figure 1): managerial experience; market entry share, market distance; young age; and network size.

Figure 1 about here

Our main contribution is that we study empirically configurations of opportunism. A configuration represents a number of contextual antecedents that must be in place simultaneously for opportunism to occur. This has not been recognised in the IB entry mode literature. First, as noted above, much of the literature suggests that opportunism can easily be anticipated and eliminated through proper governance. Second, most researchers have either assumed the presence of opportunism as a generalised behavioural antecedent, or have focused on individual causes, such as asset specificity (Tsang, 2006; Verbeke and Greidanus, 2009). Our findings differ sharply with the prevailing view of a single antecedent of opportunism. Instead we identify in our data five configurations of antecedents of opportunism (see Figure 2 in the Results section); one of them being the case of older firms with experienced managers and a large network entering geographically very distant markets. 
Identifying configurations such as the one above is important for the dialogue between theory and empirics, and between research and managerial practice. It is configurations of variables taking on particular scores that lead to opportunism, rather than individual variables used as proxies for firm-level vulnerabilities, and whose main effect might then be moderated by other variables.

\section{LITERATURE REVIEW}

TCE predicts that firms will choose the governance mode that minimizes their exposure to potential opportunism. For instance, sellers of difficult-to-patent knowledge will insist on safeguards to reduce the potential loss due to unauthorised use by buyers (Rugman, Verbeke, and Nguyen, 2011; Williamson, 1985). However, firms exhibiting some prima facie vulnerability to contract violations by opportunistic actors do not necessarily become targets of opportunism (Luo et al., 2009). Opportunistic behaviour occurs in specific contexts, but past analysis demonstrates that it may be absent even in the presence of clear vulnerabilities (Nordberg, Campbell and Verbeke, 1996). Tsang (2006, p. 1005) suggests that 'the debate [surrounding the behavioral assumption of opportunism] mainly consists of theoretical exchanges'. Other scholars corroborate Tsang's (2006) view that further research is needed to clarify the conditions under which opportunism affects different types of transactions (David and Han, 2004; Verbeke and Greidanus, 2009).

The paucity of empirical studies directly examining opportunism and its antecedents in the context of international market entry may stem from measurement difficulties. Yet, as argued by Verbeke and Greidanus (2009), it is important to study opportunism as an outcome ${ }^{3}$, and to analyze under which conditions it occurs. The focus, therefore, should be on examining 
configurations of opportunism as opposed to adopting opportunism as an untested assumption about human nature (John, 1984; Wathne and Heide, 2000), according to which one either assumes that opportunism is absent because firms have made optimal decisions, or that it results from the presence of a single, supposedly salient antecedent. In this study, we examine opportunism by importers against exporters entering new foreign markets.

\section{CONTEXTUAL ANTECEDENTS OF OPPORTUNISM}

We searched the top-ranked journals publishing IB and strategy research for studies that had 'opportunism' or 'opportunistic' along with 'market entry' in their title and abstract. We first searched the ABI/INFORM Collection Database, and subsequently the search engines of the relevant scholarly journals, and finally Google Scholar. After excluding duplicate findings and articles that were not relevant, we ended up with 65 studies, 42 conceptual and 23 empirical. ${ }^{4}$

Table 1 summarizes our findings. In spite of its importance in IB theorizing, few studies have analysed opportunism in international transactions (e.g., Ju et al., 2011; Luo, 2007a, 2007b; Zhou and Xu, 2012). We focus on five antecedents of opportunism derived from the IB literature. Table 1 also includes other relevant variables, which we control through research design and sample selection. For example, we focus on a narrow range of transactions (sales of semi-finished textiles by Chinese firms to new clients located in new foreign markets), as well as on a specific type of firm (small manufacturing exporters). This allows us to control for the possibility that some features of the transaction, such as its knowledge intensity or the industry and product at hand, would affect the level of opportunism in our observations (Zachary et al., 2015).

In the following section, we identify a number of antecedents of opportunism in market entry and in each case formulate a proposition. We do not use the term 'hypothesis' as we do not 
measure the correlation between an antecedent and opportunism, but rather examine the combinations of antecedents linked to opportunism.

Insert Table 1 about here.

\section{Managerial experience}

Managers call on past international experience to deal with the complexity and uncertainty of entering multiple markets that differ in terms of cultural, institutional, and economic characteristics (Hutzschenreuter and Voll, 2008). Their international experience helps them design proper safeguards when entering new markets (Narula and Verbeke, 2015; Reuber and Fischer, 1997; Zachary et al., 2015). As one highly experienced Chinese manager in our sample stated 'I did not know much about the United States, but, having already managed several international contracts, I had an idea of what to do...before concluding the contract we searched for all possible information on the buyer to see whether the firm seemed reliable' (Interview, Alpha Textiles). ${ }^{5}$

The international experience of the individual in charge of foreign expansion moves may compensate for a firm's lack of organizational experience. Thus, having managers who are highly experienced in international markets can help firms reduce their liability of foreignness as well as their liability of smallness and newness, thus avoiding opportunism when entering new markets. Although often discussed at the conceptual level, there is no prior empirical study assessing whether the absence of international managerial experience does lead to opportunism (see Table 1). We formulate our first proposition as follows:

Proposition 1: In the context of new foreign market entry, an exporter's limited managerial experience is associated with greater importer's opportunism. 


\section{Market entry share}

Our sample consists of firms engaged in similar transactions — sales in new foreign markets by manufacturers of semi-finished textile products to trading houses specializing in textile imports. However, these transactions differ in terms of their importance to the exporting firm, with some contracts accounting for the majority of the exporter's annual foreign sales, and others representing much smaller shares.

An exporter selling a large share of the firm's total exports would be expected to be in a weaker bargaining position vis-à-vis an importer, and hence be more vulnerable to its opportunistic behaviour (Klein et al., 1990). In the case of one of the firms in our sample, the export manager negotiating a very large shipment suspected that the importer was distorting information to obtain a discount. Nonetheless, the export manager decided to go ahead with the sale, precisely because it was for a large share of the firm's total exports. The export manager's suspicions were later confirmed.

An alternative argument is that an exporter with a smaller number of international buyers can devote more time and resources to crafting effective contractual safeguards ex ante and to monitoring contract execution compliance ex post (Jorde and Teece, 1990). However, on balance, we anticipate more opportunism when market entry share is large because of increased exporter vulnerability, which prevents exporters from introducing more effective safeguards. It is important to note that in our empirical context importers are substantially larger than exporters, and so the assumption of similar vulnerability does not hold. This leads to our second proposition:

Proposition 2: In the context of new foreign market entry, an exporter's larger market entry share is associated with greater importer's opportunism.

\section{Market distance}


Empirical evidence shows that entry into distant markets can have negative performance implications (Hutzschenreuter and Voll, 2008) because of greater information asymmetry and greater liability of foreignness (Chakrabarti and Mitchell, 2016; Verbeke, 2013). This is especially true for smaller firms (Lopez, Kundu, and Ciravegna, 2009), although even the largest multinational enterprises struggle with distance once outside the comfort zone of their home region (Rugman and Verbeke, 2004).

One of our Chinese respondents told us that it was much more difficult to manage a first sale in Europe than in Australia. Real-time communication was more challenging across five time zones than over one or two and face-to-face negotiations harder still because of the additional time and expense of travel. The result was that several details that might have otherwise been caught were left underspecified in the formal contract.

We therefore include distance in our model. To keep the empirical analysis feasible and parsimonious, especially in terms of the number of possible combinations of values for the antecedents, we consider only geographic distance. While much contemporary IB work identifies a variety of distance dimensions, including cultural and institutional distance, a large body of empirical literature demonstrates that geographic distance is still the main distance dimension affecting IB transactions. Dow and Karunaratna (2006, pp. 593-94), for example, find that 'Geographic distance accounts for almost twice as much total variance explained as all the other psychic distance stimuli combined; and this is for a set of industries (Conlon, 1985) explicitly identified as having low transportation costs!' We formulate our third proposition as follows:

Proposition 3: In the context of new foreign market entry, a greater geographic distance for the exporter is associated with greater importer's opportunism. 


\section{Young age}

Firms acquire organizational knowledge by documenting successful and unsuccessful events, and then crafting managerial practices to help managers in future endeavours. Younger firms have less opportunity to acquire and codify such information. This makes them more susceptible to opportunism, a point captured by the 'liability of newness' concept (Brüderl and Schussler, 1990; Markman et al., 2009; Mudambi and Zahra, 2007; Stinchcombe, 1965). One exporter in our sample confirmed this in saying that the firm had been exporting for many years and had developed processes specifying what to do when entering a new market, and that this had helped when encountering opportunistic behaviour on the part of importers. Our fourth proposition is therefore:

Proposition 4: In the context of new foreign market entry, an exporter's younger age is associated with greater importer's opportunism.

\section{Network Size}

Firms can leverage networks to mitigate the risk of importer opportunism (Ellis, 2011; Zhou et al., 2007). A network can provide access to information not readily available elsewhere (Ciravegna et al., 2014; Johanson and Vahlne, 2009). We only consider networks that exporters can access for local market intelligence-we do not consider the networks of the importers. We therefore include network size as one of the antecedents of opportunism. We do recognize that other network characteristics such as centrality and frequency can be important, but no reliable data on these dimensions were available from our survey instrument. Our fifth proposition is:

Proposition 5: In the context of a new foreign market entry, an exporter's smaller network is associated with greater importer's opportunism.

\section{Aligning theory and research methods}


Actual opportunistic behaviour results from several explanatory variables taking on specific values at the same time. Each situation should be looked at in its entirety. Rather than seeing opportunism simply as taking the value of 0 (not present) or 1 (present) as a function of narrow transaction characteristics and the use of safeguards ( $\mathrm{s}=0$ or $\mathrm{s}>0$ ), as put forward by Williamson (1985), we consider important antecedents of opportunism and their interactions so as to identify configurations of opportunism. Investigating such configurations can greatly improve our understanding (Luo, 2007a; Rugman et al., 2011; Verbeke and Greidanus, 2009).

Our approach is different from that of extant studies of opportunism in the IB literature that search for linear relationships between causes and effects (Welch et al., 2011). That approach can hide the impact of configurations of antecedents of opportunism (i.e., joint effects), although these might actually drive the results (Fiss, 2011). In novel international settings, for example, the lack of an experienced manager may lead to opportunism only when the exporting firm is small and young, while larger and older exporters may be better equipped to leverage their domestic experience.

Here, we examine opportunism using a configurational approach. We study the combinations of factors that lead market entries to be vulnerable to opportunistic behaviour by importers. The configurations we examine also provide insight into what could be done to mitigate opportunism. In the next section we explain our methodological approach in more detail.

\section{METHODS}

\section{Data and Definitions}

Entering a new market entails managing in a previously unknown context with possible adverse consequences (Carmeli and Markman, 2011). We examine the antecedents of 
opportunism in international market entry, defining opportunism as deceitful behaviour that amounts to explicit or implicit contract violations. We follow the suggestion that scholars should study the 'wider set of antecedents, contingencies, and consequences' of market entry (Journal of Management Studies [Call for Papers], 2016).

Our market entries are the initial export sales of Chinese textile producers to new target countries. In line with other studies of Chinese firms (Verbeke and Yuan, 2013), we collected data through face-to-face interviews with the highest-placed international sales managers available, in most cases the firm's general manager. The interviews took place between January 2008 and December 2009. They were conducted in Cantonese or Mandarin with the support of a local consultant.

Collecting empirical evidence on opportunism, especially from Chinese firms, is challenging, and so we were not able to obtain dyadic data on outcomes (Verbeke and Yuan, 2013; Zhou and Xu, 2012). This is not a critical weakness. Opportunism involves a 'victim' and a 'violator'. If the goal of the research had been to assess the veracity of exporting firms' claims of contract violation, it would have made little sense to listen to the self-described victims without considering the views of the other party. We consider the claim of deceitful behaviour to be true because each victim identified some instances where deceit was absent.

Following Podsakoff et al. (2003) and Chang et al. (2010), we took several steps to control for common method variance. We conducted a pilot study with 13 firms to verify the clarity and appropriateness of the interview items and to explore potential sources of ambiguity and used the results to alter our instrument. We assured our respondents that their answers would remain confidential and that there was no 'correct' answer to any question. We used filtering questions in the questionnaire and interspersed questions about opportunism with requests for basic 
information on the firm and about the industry (Murray et al., 2005). Filtering questions creates psychological breaks between questions on outcomes and antecedents, which helps control for potential common method variance (Conway and Lance, 2010; Kammeyer-Mueller et al., 2010; Podsakoff et al., 2003). We also gave the respondents a temporal and psychological break by interrupting the interview with offers of refreshments and questions unrelated to the research. We ensured that our model included both perceptual and non-perceptual variables, as well as different measurements and scales (Chang et al., 2010).

Our outcome, the presence or absence of opportunism, is a perceptual parameter, based on six Likert-scale items. All other variables are factual and continuous at the outset (managerial experience, market distance, network size, young age) except for market entry share, which is a percentage. We measured firm age and geographic distance using the information provided by the respondents, which we corroborated with archival data and official registries.

Our sample consists of locally-owned, small Chinese exporters (defined as firms with less than 250 employees, in line with the OECD 2005 criterion for smallness) willing to make available for interview the most senior manager in charge of the market entry (general manager or high-level export sales manager). We did not include large firms because we wanted to be certain that we talked to the actual managers responsible for specific foreign sales contracts. ${ }^{6}$ After excluding firms with missing data, and firms unwilling or unable to disclose information about their market entries, we were left with 38 firms making a total of 133 market entries. The firms entered new markets by selling to importers, who then further distributed the products to corporate buyers. Each exporter made on average 3.5 market entries, with a minimum of two and a maximum of six. We documented each market entry via interviews with the respondents and 
complemented the interviews with archival data. We now describe the method we used and the operationalization of our variables.

\section{Data Analysis: fsQCA}

We used fsQCA, a method based on fuzzy sets that has been applied several times in recent strategy research (Fiss, 2011; Judge et al., 2015; Kennedy and Fiss, 2013; Misangyi et al., 2017; Brenes, Ciravegna, and Woodside, 2017). There are three main reasons why fsQCA is an appropriate methodological approach for this study. First, opportunism is critical in TCE, but empirical evidence on it, especially in the context of new market entry, is scant (Tsang, 2006). We needed to test assumptions by establishing typologies and assessing interactions. Second, TCE comes into sharper focus when its assumptions are addressed in a 'configurational' fashion. Williamson (1985, p. 31) describes, at the general theory level, the attributes of the contracting process in configurational terms, arguing that four contracting processes arise from different combinations of behavioural assumptions and asset specificity. In one example, he argues that in the absence of opportunism, but when bounded rationality and asset specificity are present, the implied contracting process is a 'promise'. He sees contracting processes as resulting from configurations of antecedents. Third, correlational methods assume relationships among variables that are additive and symmetrical, but we are interested in complex relationships among contextual variables that may show different paths to outcomes (equifinality). We do not argue that this approach is superior to conventional correlational methods, but we do consider fsQCA uniquely suitable to address the type of research question we explore.

The fsQCA empirical approach is based on fuzzy sets. FsQCA allows us to examine the extent to which each market entry 'belongs' (full membership) or 'does not belong' (full nonmembership) to the set of entries affected by opportunism, or whether it falls somewhere between 
the two extremes. This determination process, called 'calibration', is explained in more detail below.

Following established practice in fsQCA studies (Fiss et al., 2013), we calibrated all variables--the outcome variable opportunism and the five antecedents--using three values. The value of 1 represents full membership. It reflects the market entries that are fully and clearly positioned within a set, for example entries that clearly occurred in a distant market. The value of 0 represents full non-membership, or market entries that are clearly outside a given set, for example an entry clearly targeting a market that was not distant. The value of 0.5 represents the point of 'maximum ambiguity', or the score that defines a boundary between being 'in' or 'out'. We calibrated membership of the market entries into the corresponding fuzzy sets using knowledge from prior empirical studies and other external benchmarks (Fiss et al., 2013, pp. 417). Below, we explain how fsQCA was applied to the outcome variable and to each of the five antecedents.

\section{Opportunism and its Antecedents}

Opportunism. Building on earlier research (Ju et al., 2011; Katsikeas et al., 2009; Parkhe, 1993; Provan and Skinner, 1989), we measured opportunism through an instrument based on John (1984). ${ }^{7}$ The 1 to 7 Likert scale presented to the respondents reflected views ranging between ' 1 ' for 'very strongly disagree' and '7' for 'very strongly agree'. We averaged the values received for each of the six items to establish the presence of opportunism $(\alpha=0.95)$. In our survey instrument, a score of 7 entails full membership in the set of market entries associated with opportunism, whereas a score of 1 entails full non-membership in the same set. Thus, the outcome variable, opportunism, was calibrated by setting 7 as the full membership score (i.e., high opportunism by the importer), and 1 as the full non-membership score (no opportunism). We chose 4, the 
midpoint of the scale reflecting the answer 'neither agree, nor disagree', as the point of maximum ambiguity following fsQCA method guidelines (Schneider and Wagemann, 2012). Since we use fuzzy sets, 'continuous set' memberships were determined using the log odds method outlined by Ragin (2008). Through this fsQCA calibration process, necessarily performed for both the outcome variable and each antecedent, we were able to distinguish between the market entries affected by opportunism and those not affected by it, and the configurations of antecedents associated with opportunism. The configurations illustrated in Figure 2 represent the entries affected by opportunism.

Managerial experience. Empirical evidence suggests that experienced managers can compensate for the absence of other opportunism-mitigating mechanisms, such as internalizing transactions or relying on a firm's routines developed over time (Narula and Verbeke, 2015; Reuber and Fischer, 1997). We measured this variable using the number of years of international experience the export manager had at the time of market entry. Such experience is typically associated with better decision-making (Taylor, 1975). In business research, managerial experience is often considered a dichotomous variable (i.e., the firm's managers have experience or not). Yet, it is hard to determine how much experience is required to obtain a better outcome. In our view, making a crisp distinction between firms with managers who have experience and those who do not, would not be optimal since the length of experience is also relevant. Our data show managers with as much as 33 years of experience and as little as one, with a median of five years, and a similar standard deviation. We define zero years of experience as the reference point for full non-membership into the set of market entries with managerial experience. A total of five years of experience defines the point of maximum ambiguity, whereas we chose 20 years (i.e., the fiveyear median, augmented by three standard deviations) as the anchor indicating full membership in 
the set of entries by firms with managerial experience. We validated our calibration using prior research (see Brooks and Rosson, 1982; Forbes, 2005; Garnier, 1982; Karafakioglu, 1986; Sambharya, 1996; Shrader et al. 2000; Taylor, 1975).

Market entry share. Market entry share is the percentage of total firm exports represented by the market entry in the year following entry. This is a proxy for the importance of the market entry for the exporting firm. The larger the market entry share, the more we expect the export manager to want to 'close the deal', making the exporting firm vulnerable to opportunistic behaviour by the importer. Our data show market entry shares varying between $2 \%$ and $80 \%$ of total exports, with a mean value of $21 \%$. We defined a $0 \%$ share as the reference point for full non-membership in the set large market entry share, and a $22.5 \%$ share as the point of maximum ambiguity. We selected $22.5 \%$ as a 'midpoint' between 20 and 25 in order to avoid the specific values of $20 \%$ and $25 \%$, each with several observations, as this would have meant losing many data points. The respondents were well aware of the share of each market entry, but typically stated percentages in rounded terms (such as $20,25,50$ or $80 \%$ ). We chose $100 \%$ as the anchor for full membership in the large market entry share category. We could not rely on any prior literature to establish credibly the market entry share that makes an exporter vulnerable to opportunism, but settled, based on the interviews, on a share of one fifth to one quarter.

Market distance. Distance amplifies information asymmetries and the challenges of operating in a new, unknown, market (i.e., the liability of 'outsidership'). Exporters who are less familiar with distant markets will need to implement costlier measures to prevent opportunism by importers (Hutzschenreuter and Voll, 2008). Such measures can include meeting abroad with the importing firm before signing the contract or whenever major problems arise in contract execution. 
As said earlier, we only consider geographic distance to keep the number of possible combinations in the fuzzy sets manageable. Geographic distance is relevant from a semiglobalization, or home region versus rest of the world, perspective (Rugman and Verbeke, 2007). It results in large reductions in general levels of perceived reliability and sympathy (Ghemawat, 2011). We measured it as the distance in kilometers from the exporting port to the main port of the importing country, using the online calculator of SeaRates.com (2014). Our data show that our exporters either make regional exports to countries located within a 4,000 km range from China (Hong Kong, Taiwan, and Thailand) or target more distant countries (e.g., the United States, Italy, Argentina). We chose zero $\mathrm{km}$ as the reference point for full non-membership in the set of distant market entries and 4,000 $\mathrm{km}$ as the point of maximum ambiguity because this is the distance at which intra-regional exports morph into inter-regional ones. We chose $11,000 \mathrm{~km}$, being close to the highest port-to-port distance in our observations, as the anchor indicating full membership in the set of distant market entries. This is the case of Argentina, which is fully in the set of highdistance entries. In contrast, Taiwan, with the shortest distance from China, is close to full nonmembership in the set of distant market entries, while Saudi Arabia is close to the point of maximum ambiguity.

Young age. Firm age is a proxy for organizational experience. Older firms have accumulated more organizational experience, and are better prepared to anticipate and prevent opportunism. For example, they are likely to document cases of opportunistic behaviour and structure internal decision-making processes to prevent its occurrence in future sales. Younger firms, on the contrary, suffer from the liability of newness, and this may make them more vulnerable to opportunism (Brüderl and Schussler, 1990; Mudambi and Zahra, 2007; Stinchcombe, 1965). We measured firm age as the number of years between the birth of a firm 
and the year of market entry. We conducted a literature review to guide us in selecting relevant intervals for calibration. A number of authors define 'early' internationalization as occurring within three years of a firm's founding (Zhou et al., 2007), while others suggest a timespan of five to six years (Zahra et al., 2000). Firm age at internationalization ranges from zero to 21 years, with a median of three years. Following Zahra et al. (2000), we chose zero years for full membership in the set of young age, i.e., the set of firms that exported within the first year after inception, and six years as the point of maximum ambiguity, which defines the boundary between being 'in' or 'out' of the set of young firms. We doubled this number, and chose 12 years as the year of full non-membership in the young age set of firms (with all firms older than 12 years also having full non-membership). We defined continuous set memberships using the log odds method outlined by Ragin (2008); we did not code firms simply as young or old but established degrees of membership in the set of early exporters. As with the other variables, fuzzy sets allow establishing how far a firm is removed from one or the other extreme, and following this approach, fuzzy set principles can be used to explore the questions of interest (Ragin, 2006).

Network size. Exporting firms use networks to acquire information about new markets and about the importers in them (Ellis, 2011). The information thus obtained can help mitigate the risk of opportunism in market entry. The network in this instance is likely to signal which importers to avoid because of a reputation of deceitful behaviour (Ciravegna et al., 2014). Exporters who do not have a large enough network will rely on 'arm's length' resources, for example publicly available information on a potential importer's financial situation, but such information may be insufficient to signal the likelihood of opportunism. We measure the size of the exporters' network by asking how many personal contacts they have in each market entered. Our data show this to be 15.2 on average, with a median of 10 and a range of three to 100 . The data were highly 
dispersed, with some concentration around 'tentative' scores of 10 contacts (in 34 cases) and 20 contacts (in 15 cases). The precision of this information is fully dependent on the recollection of the individual interviewees of the situation at the time of entry, rather than at the time of the interview. Here again our assessment is that the quality of the recollection was typically good, but that managers gave rounded numbers for larger networks. To validate our calibration we relied on external sources following fsQCA guidelines (Schneider and Wagemann, 2012). In a study of firms based in emerging economies, Batjargal (2007) reports the mean size of networks of smaller firms in China and Russia at 3.92 (with a standard deviation of 1.45) and 4.63 (with a standard deviation of 1.13). Drawing upon these findings, we set 4.5 as the point of maximum ambiguity, 0 as the threshold score indicating that the market entry is fully outside the set of entries by firms with a large network size, and 25 as the number of contacts qualifying a firm for full membership in such a set.

\section{The fsQCA Model}

Having calibrated each market entry (see summary in Table 2), we identified plausible configurations of opportunism.

Insert Table 2 about here.

In fsQCA, 'consistency' is used to measure how strongly configurations (or combinations of factors) are linked to an outcome, in our case opportunism. We measured it using the following equation: Consistency $(\mathrm{Xi} \leq \mathrm{Yi})=\Sigma[\min (\mathrm{Xi}, \mathrm{Yi})] / \Sigma(\mathrm{Xi})$, with $\mathrm{Xi}$ the degree of membership in a configuration and Yi the degree of membership in the actual outcome (Ragin, 2008). Table 3 shows the values of plausible configurations with the chosen minimum threshold and the corresponding consistency values. 
Insert Table 3 about here.

We used a consistency threshold of 0.85 , following the fsQCA method literature (Ragin, 2000; Schneider and Wagemann, 2012). We chose this consistency threshold as the basis to claim 'sufficiency' for the plausible configurations considered, within the confines of our limited dataset.

Insert Table 4 about here.

\section{Results}

We found five configurations of antecedents linked to opportunism in the context of foreign market entries of Chinese textile exporters (Table 4). The formal Boolean expression for the outcome of opportunism is:

$$
\mathrm{Y} \sim \mathrm{N} \sim \mathrm{E}+\mathrm{YD} \sim \mathrm{E}+\mathrm{YS} \sim \mathrm{D} \sim \mathrm{N}+\mathrm{DE} \sim \mathrm{Y} \sim \mathrm{S}+\mathrm{DEN} \sim \mathrm{Y} \rightarrow \mathrm{O}
$$

The letter O represents the outcome of opportunism, Y (young age) the antecedent 'belonging to the set of firms that internationalised early'; E having an experienced manager (which we expect helps avoid opportunism); $\mathrm{N}$ having a large network (which again, we expect helps avoid opportunism); D having entered a distant market; and S an entry that accounts for a large share of total exports in the year it occurred. The sign ' $\sim$ ' appearing on the left of an antecedent indicates non-membership in a given set. If $\sim \mathrm{D}$ appears as an antecedent, it means not belonging to the set of entries into distant markets.

Table 4 summarizes the results. Each column represents a combination of antecedents, or a configuration, linked to opportunism. Black circles indicate that the presence of an antecedent links to the outcome. For example, young age was an antecedent of opportunism in configurations 
1, 2 and 3. A white circle with a cross indicates that opportunism links with the absence of the antecedent. For example, absence of managerial experience led to opportunism in configurations 1 and 2. A white square in the table means that the presence or absence of the antecedent did not affect the outcome. Having a large network size was not relevant for opportunism in configurations 2 and 4 . Figure 2 describes the five configurations.

Figure 2 about here

\section{DISCUSSION}

The objective of this study was to examine opportunism and its antecedents in the context of entries into new foreign markets. We found five configurations that are 'equifinally' linked with opportunism, three involving firms that internationalised at a young age, and two involving older firms. These configurations, each reflecting a complex context of antecedents, imply that the firms involved faced opportunistic behaviour from importers when entering a new market under the following conditions.

Configuration 1 - Young firms lacking both an experienced manager and a large network. A young firm will face opportunism when entering a new market if it is without an experienced export manager and also without a sizeable network in the host country, irrespective of geographic distance. This configuration illustrates the challenges of entering a new market for firms that lack experience and networks, whether at the level of the manager or that of the organization, captured through firm age. We find evidence that young firms without experienced managers and sizeable networks are vulnerable to opportunistic behaviour by importers when entering new markets, which is consistent with the mainstream literature on market entry (see e.g. Markman et al., 2009; 
Zachary et al., 2015), and with IB studies on networks (Johanson and Vahlne, 2009) and experience (Reuber and Fischer, 1997). From a managerial perspective, this configuration suggests that young firms should compensate for the liability of newness with managerial experience and larger networks.

Configuration 2 - Young firms lacking an experienced manager and entering a distant market. A young firm will face opportunism when lacking managerial experience and entering a distant market, irrespective of the size of its network. This configuration reveals the interplay between distance, firm age, managerial experience, and networks. It shows that if the market entered is distant, a young firm without an experienced manager can be subject to opportunism even if it has a large network. The managerial implication in this case is that networks, which can compensate for the lack of managerial experience and for the liability of newness (Coviello, 2006), will not be effective when the target market is very distant.

Configuration 3 - Young firms lacking a large network, entering a non-distant market, with a large market entry share. A young firm without the benefit of a sizeable network will face opportunism when engaging in a geographically close market entry that represents a large share of its total exports, irrespective of managerial experience. This configuration reveals the complexity of the antecedents of opportunism. Managerial experience is an important mechanism to mitigate opportunism and facilitate market entry, as shown by extant research (Zachary et al., 2015). However, it is not sufficient to prevent opportunism in all market entries. Our study suggests that when an entry represents a large share of the firm's total sales, young exporters may be too willing to close the deal as the perceived opportunity costs of forfeiting it will appear too high. As one manager described it, the fear that the 'stakes are too high' causes a young firm to move ahead without exercising due diligence, thus exposing itself to opportunism (Interview, Beta 
Textiles). ${ }^{8}$ The managerial implication in this case is that the incentive to conclude a large sale should never be allowed to override due diligence when entering a new market, even when the decision maker is experienced.

Our results suggest that being a 'young' firm can lead to opportunistic behaviour by importers in a number of instances when there is a gap between a firm's capabilities and the challenges it faces. In contrast, configurations 4 and 5 feature older firms, which do not suffer from the liability of newness.

Configuration 4 - Older firms with an experienced manager, entering a distant market, with a small market entry share. An older firm with an experienced manager will face opportunism when entering a distant market with a sale representing a small share of its total exports, irrespective of the size of its target country network. Here, small contract size causes experienced exporters to fail to put in place proper safeguards. As one manager put it, "We should have been more careful. It was a small contract, so we lowered our guard" (Interview, Gamma Textiles). ${ }^{9}$ This configuration illustrates the interplay between distance and transaction size, even in the presence of antecedents that should prevent opportunism such as being an old firm and having experienced managers. This case shows the importance of capturing causality through configurations. Although younger firms may be more vulnerable when negotiating a large sale, older firms with experienced managers may be more at risk when negotiating a small one in a distant market because they knowingly underinvest in due diligence.

Configuration 5 - Older firms with an experienced manager and a large network, entering a distant market. This configuration is one commonly discussed in the extant literature, whereby established firms with experienced managers and extensive networks enter a high distance market and tend to underestimate the extent to which distance increases the liability of foreignness, and 
thus also the risk of opportunistic behaviour by importers (Verbeke and Kano, 2016; Eden and Miller, 2004). It illustrates that firms that have mechanisms to prevent opportunism, including experienced managers and networks, can still be victims of opportunistic behaviour when the markets entered are truly distant. At the theoretical level, our findings confirm that, absent mechanisms to internalize transactions, a firm may experience opportunistic behaviour when entering new markets, as assumed by most studies of entry mode choice in the IB literature, and that geographical distance continues to be an important challenge (Tung and Verbeke, 2010; Verbeke and Ciravegna, 2018). From a managerial perspective, the implication is that in some specific contexts, such as that of a small exporter entering a distant foreign market, it may simply not be possible to eliminate the risk of opportunism short of fully internalizing the transactions involved. However, this solution may not be feasible given the one-shot nature of the contracts.

\section{CONCLUSIONS}

Much extant IB research on market entry has assumed opportunism (Hennart, 2010). Whether firms will enter foreign markets through equity-based investments or contracts is at least partly dependent on how human frailty can best be managed (Narula and Verbeke, 2015). Yet, IB studies have seldom examined the conditions under which opportunism occurs, and this has had two effects. First, the absence of empirical work on opportunism has reduced the predictive power of theory-based assertions for which the assumption of opportunism is critical. Second, opportunism has remained under-contextualised, with most studies focusing on just one of its antecedents (Tsang, 2006; Verbeke and Greidanus, 2009).

The discrepancy between what research has assumed and what it has actually measured, is the research gap we have tried to address. To our knowledge, our study is the first one in the international market entry literature to measure directly the antecedents of opportunism using 
empirical evidence from decision makers actually involved in market entries. In contrast to what prior literature suggests, we show that no single variable, such as the young age of firms, is by itself a sufficient antecedent of opportunism in new foreign market entry. Instead, specific configurations of antecedents must be in place for opportunism to surface, and there can be multiple configurations equifinally linked to importer opportunism. One can interpret these configurations as syndromes - sets of elements working together to create a scenario where deceitful economic actors can exploit an exporting firm's vulnerability. We found support for opportunism, a basic, yet mostly untested, tenet of TCE-based analysis. When alternative structural governance mechanisms such as internalization are not feasible, opportunism does occur if a number of conditions are in place, even if firms have experienced managers and a large network in the target country (Coviello, 2006; Reuber and Fischer, 1997; Verbeke and Ciravegna, 2018).

The analysis of opportunism as an observed outcome arising in particular entry contexts, rather than as a human dispositional trait, suggests that this concept needs further review. As argued by Verbeke and Greidanus (2009) and Kano and Verbeke (2015), multiple managerial tools can be deployed to limit the occurrence and effects of opportunism, but even absent such tools, there may be particular market entry contexts in which opportunism is unlikely to occur, in spite of the clear presence of a vulnerability to contract violation. ${ }^{10}$ There are also specific conditions under which opportunism can affect firms in spite of the presence of elements that should help prevent it, such as managerial experience and large networks.

The present study thus establishes a much-needed bridge between scholarly work based on TCE, which assumes opportunism as a default behavioural trait, and the practical needs of managers to anticipate and mitigate the effects of deceitful behaviour in international market 
entries. The five configurations of antecedents to opportunism we identified lay a basis for actionable dialogue with managers on why opportunism sometimes occurs, and on the panoply of tools deployable to handle it (see also the rich contextual business case described in McGaughey et al., 2000).

Our study's main limitation is its focus on Chinese exporters of low-tech products. Future research should examine the conditions under which opportunism can affect larger firms even though they are often able to safeguard transactions vulnerable to opportunism by opening subsidiaries abroad. Another promising avenue for extending this research would be to examine opportunism by exporters against importers and suppliers. This would permit identifying 'patterns' of who engages in opportunism in what particular conditions, who suffers its consequences, and which managerial tools could be deployed by potential victims to avert it. Future work could also experiment with alternative measures of distance and networks. For purposes of parsimony, we looked at a relatively small set of five, theory-derived, contextual antecedents of opportunism. Looking at other contexts would also help further develop the theory. Lastly we focused on exporters of low-tech products entering new markets. The question arises whether the configurations of opportunism that we identified would still hold in the case of exports of higher-technology products or services, and for sequential entries in the same market.

Despite these limitations, our study can be a building block for a revitalised research agenda on international market entry. Our approach is conceptually grounded in mainstream IB theory, but adopts a configurational approach and allows constructive interaction with practicing managers in search of tools to identify and mitigate their firms' vulnerabilities. Paradoxically, an increasing segment of the recent IB literature considers vulnerabilities resulting from frail macrolevel institutions such as inadequate regimes of protection of intellectual property rights. It is 
important that the scholarly community continues to address at the micro-level how firms are vulnerable to the deceitful behaviour of business partners. We would like to see more research directed towards improving our understanding of the business context of opportunism.

\section{REFERENCES}

Batjargal, B. (2007). 'Comparative social capital: Networks of entrepreneurs and venture capitalists in China and Russia'. Management and Organization Review, 3, 397-419.

Brenes, E. G., Ciravegna, L., and Woodside, A.R. (2017) 'Constructing useful models of firms' heterogeneities in implemented strategies and performance outcomes.' Industrial Marketing Management, 62, 17-35.

Brooks, M. R. and Rosson, P. J. (1982). ‘A study of export behavior of small and medium-sized manufacturing firms in three Canadian provinces'. In Czinkota, M. R., and Tesar, G. (Eds.), Export Management: An International Context. New York: Praeger Publishing, 39-54.

Brouthers, K. D. (2002). 'Institutional, cultural and transaction cost influences on entry mode choice and performance'. Journal of International Business Studies, 33, 203-21.

Brown, J. R., Dev, C. S. and Lee, D. J. (2000). 'Managing marketing channel opportunism: The efficacy of alternative governance mechanisms'. Journal of Marketing, 64(2), 51-65.

Bruderl, J., and Schussler, R. (1990). 'Organizational mortality: The liabilities of newness and adolescence'. Administrative Science Quarterly, 35, 530-47.

Buckley, P. J. (2016). 'The contribution of internalisation theory to international business: New realities and unanswered questions'. Journal of World Business, 51, 74-82.

Buckley, P. J. and Casson, M. C. (1998). 'Analyzing foreign market entry strategies: Extending the internalization approach'. Journal of International Business Studies, 29, 539-61. 
Buckley, P. J. and Casson, M. C. (2009). 'The internalisation theory of the multinational enterprise: A review of the progress of a research agenda after 30 years'. Journal of International Business Studies, 40, 1563-80.

Buckley, P., Devinney, T. and Louviere, J. J. (2007). 'Do managers behave the way theory suggests? A choice-theoretic examination of foreign direct investment location decisionmaking'. Journal of International Business Studies, 38, 1069-94.

Caniëls, M. C. and Gelderman, C. J. (2010). 'The safeguarding effect of governance mechanisms in inter-firm exchange: The decisive role of mutual opportunism'. British Journal of Management, 21, 239-54.

Carmeli, A. and Markman, G. D. (2011). 'Capture, governance, and resilience: strategy implications from the history of Rome'. Strategic Management Journal, 32, 322-41.

Carson, S. J., Madhok, A. and Wu, T. (2006). 'Uncertainty, opportunism, and governance: The effects of volatility and ambiguity on formal and relational contracting'. Academy of Management Journal, 49, 1058-77.

Chakrabarti, A. and Mitchell, W. (2016). 'The role of geographic distance in completing related acquisitions: Evidence from US chemical manufacturers'. Strategic Management Journal, 37, 673-94.

Chang, S. J., Van Witteloostuijn, A. and Eden, L. (2010). 'From the editors: Common method variance in international business research'. Journal of International Business Studies, 41: $178-84$.

Ciravegna, L., Lopez, L. and Kundu, S. (2014). 'Country of origin and network effects on internationalization: A comparative study of SMEs from an emerging and developed economy'. Journal of Business Research, 67, 916-23. 
Conlon, R.M. (1985). Distance and Duties: Determinants of Manufacturing in Australia and Canada. Ottawa: Carlton University Press.

Conway, J. M. and Lance, C. E. (2010). 'What reviewers should expect from authors regarding common method bias in organizational research'. Journal of Business and Psychology, 25, $325-34$.

Coviello, N. E. (2006). 'The network dynamics of international new ventures'. Journal of International Business Studies, 37, 713-31.

David, R. J. and Han, S-K. (2004). 'A systematic assessment of the empirical support for transaction cost economics'. Strategic Management Journal, 25, 39-58.

Deeds, D. L. and Hill, C. W. (1999). 'An examination of opportunistic action within research alliances: Evidence from the biotechnology industry'. Journal of Business Venturing, 14, 14163.

Dickson, P. H., Weaver, K. M. and Hoy, F. (2006). 'Opportunism in the R\&D alliances of SMEs: The roles of the institutional environment and SME size'. Journal of Business Venturing, 21, 487-513.

Dow, D. and Karunaratna, A. (2006). 'Developing a multidimensional instrument to measure psychic distance stimuli'. Journal of International Business Studies, 37, 578-602.

Eden, L. and Miller, S.R. (2004). 'Distance matters: Liability of foreignness, institutional distance and ownership strategy'. In: M.A. Hitt and J.L.C. Cheng (Eds.), The Evolving Theory of the Multinational Firm. Advances in International Management. Volume 16. Bingley, UK: Emerald Group Publishing Limited, 187-221.

El Akremi, A., Mignonac, K. and Perrigot, R. (2011). 'Opportunistic behaviors in franchise chains: The role of cohesion among franchisees'. Strategic Management Journal, 32, 930-48. 
Ellis, P. D. (2011). 'Social ties and international entrepreneurship: Opportunities and constraints affecting firm internationalization'. Journal of International Business Studies, 42, 99-127.

Fiss, P. C. (2011). 'Building better causal theories: A fuzzy set approach to typologies in organization research'. Academy of Management Journal, 54, 393-420.

Fiss, P. C., Cambré, B. and Marx, A. (Eds.). (2013). Configurational Theory and Methods in Organizational Research. Bingley, UK: Emerald Group Publishing Limited.

Forbes, D. P. (2005). 'Managerial determinants of decision speed in new ventures'. Strategic Management Journal, 26, 355-66.

Garnier, G. (1982). 'Comparative export behavior of small Canadian firms in the printing and electrical industries'. In Czinkota, M. R. and Tesar, G. (Eds.), Export Management: An International Context. New York: Praeger Publishing, 113-31.

Ghemawat, P. (2011). World 3.0: Global Prosperity and How to Achieve It. Boston, MA: Harvard Business School Press.

Handley, S. M. and Angst, C. M. (2015). 'The impact of culture on the relationship between governance and opportunism in outsourcing relationships'. Strategic Management Journal, 36, $1412-34$.

Heide, J. B., Wathne, K. H. and Rokkan, A. I. (2007). 'Interfirm monitoring, social contracts, and relationship outcomes'. Journal of Marketing Research, 44, 425-33.

Hennart, J. F. (1982). A Theory of Multinational Enterprise. Ann Arbor, MI: University of Michigan Press.

Hennart, J. F. (1988). 'A transaction costs theory of equity joint ventures'. Strategic Management Journal, 9, 361-74. 
Hennart, J. F. (2009). 'Down with MNE-centric theories! Market entry and expansion as the bundling of MNE and local assets'. Journal of International Business Studies, 40, 1432-54.

Hennart, J. F. (2010). 'Transaction cost theory and international business'. Journal of Retailing, 86, 257-69.

Hutzschenreuter, T. and Voll, J. C. (2008). 'Performance effects of "added cultural distance" in the path of international expansion: The case of German multinational enterprises'. Journal of International Business Studies, 39, 53-70.

Jap, S. D., Robertson, D. C., Rindfleisch, A. and Hamilton, R. (2013). 'Low-stakes opportunism'. Journal of Marketing Research, 50, 216-27.

Johanson, J. and Vahlne, J-E. (2009). 'The Uppsala internationalization process model revisited: From liability of foreignness to liability of outsidership'. Journal of International Business Studies, 40, 1411-31.

John, G. (1984). 'An empirical investigation of some antecedents of opportunism in a marketing channel'. Journal of Marketing Research, 21, 278-89.

Jorde, T. M. and Teece, D. J. (1990).0' Innovation and cooperation: Implications for competition and antitrust'. Journal of Economic Perspectives, 4(3), 75-96.

Journal of Management Studies. (2016). JMS Call for Papers for Special Issue, 'The Who, Where, What, How and When of Market Entry. ' Link available at: http://ie-scholars.net/blog/2616

Ju, M., Murray, J. Y., Kotabe, M. and Gao, G. Y. (2011). 'Reducing distributor opportunism in the export market: Effects of monitoring mechanisms, norm-based information exchange, and market orientation'. Journal of World Business, 46, 487-96.

Judge, W. Q., Hu, H. W., Gabrielsson, J., Talaulicar, T., Witt, M. A., Zattoni, A., López-Iturriaga, F., Chen, J. J., Shukla, D., Quttainah, M., Adegbite, E., Luis Rivas, J. and Kibler, B. (2015). 
'Configurations of capacity for change in entrepreneurial threshold firms: Imprinting and strategic choice perspectives'. Journal of Management Studies, 52, 506-30.

Kammeyer-Mueller, J., Steel, P. D. and Rubenstein, A. (2010). 'The other side of method bias: The perils of distinct source research designs'. Multivariate Behavioral Research, 45, 294-321.

Kano, L. and Verbeke, A. (2015). 'The three faces of bounded rationality: Alfred Chandler and the micro-foundations of management theory'. California Management Review, 58, 97-122.

Karafakioglu, M. (1986). Export activities of Turkish manufacturers'. International Marketing Review, 3, 34-43.

Katsikeas, C. S., Skarmeas, D. and Bello, D. C. (2009). 'Developing successful trust-based international exchange relationships'. Journal of International Business Studies, 40, 132-55.

Kennedy, M. T. and Fiss, P. C. (2013). 'An ontological turn in categories research: From standards of legitimacy to evidence of actuality'. Journal of Management Studies, 50, 1138-54.

Klein, S., Frazier, G. L. and Roth, V. J. (1990). ‘A transaction cost analysis model of channel integration in international markets'. Journal of Marketing Research, 27, 196-208.

Lado, A. A., Dant, R. R. and Tekleab, A. G. (2008). 'Trust-opportunism paradox, relationalism, and performance in interfirm relationships: Evidence from the retail industry'. Strategic Management Journal, 29, 401-23.

Leamer, E. E. and Storper, M. (2001). The economic geography of the Internet age. Journal of International Business Studies, 32, 641-65.

Lopez, L. E., Kundu, S. K., \& Ciravegna, L. (2009). Born global or born regional? Evidence from an exploratory study in the Costa Rican software industry. Journal of International Business Studies, 40(7), 1228-1238. 
Liu, Y., Luo, Y. and Liu, T. (2009). 'Governing buyer-supplier relationships through transactional and relational mechanisms: Evidence from China'. Journal of Operations Management, 27, 294-309.

Luo, Y. (2007a). 'An integrated anti-opportunism system in international exchange'. Journal of International Business Studies, 38, 855-77.

Luo, Y. (2007b). ‘Are joint venture partners more opportunistic in a more volatile environment?'. Strategic Management Journal, 28, 39-60.

Luo, Y., Liu, Y. and Xue, J. (2009). 'Relationship investment and channel performance: An analysis of mediating forces'. Journal of Management Studies, 46, 1113-37.

Markman, G. D., Gianiodis, P. T. and Buchholtz, A. K. (2009). 'Factor-market rivalry'. Academy of Management Review, 34, 432-41.

Markman, G. D. and Waldron, T. L. (2014). 'Small entrants and large incumbents: A framework of micro entry'. Academy of Management Perspectives, 28, 179-97.

McGaughey, S. L., Liesch, P. W. and Poulson, D. (2000). ‘An unconventional approach to intellectual property protection: The case of an Australian firm transferring shipbuilding technologies to China'. Journal of World Business, 35, 1-20.

Misangyi, V. F., Greckhamer, T., Furnari, S., Fiss, P. C., Crilly, D. and Aguilera, R. (2017). 'Embracing causal complexity: The emergence of a neo-configurational perspective. Journal of Management, 43, 255-82.

Mudambi, R. and Zahra, S. A. (2007). 'The survival of international new ventures'. Journal of International Business Studies, 38, 333-52. 
Murray, J. Y., Kotabe, M. and Zhou, J. N. (2005). 'Strategic alliance-based sourcing and market performance: Evidence from foreign firms operating in China'. Journal of International Business Studies, 36, 187-208.

Narula, R. and Verbeke, A. (2015). 'Making internalization theory good for practice: The essence of Alan Rugman's contributions to international business'. Journal of World Business, 50, $612-22$.

Nordberg, M., Campbell, A.J. and Verbeke, A. (1996). 'Can market-based contracts substitute for alliances in high technology markets?'. Journal of International Business Studies, 27, 963-79.

OECD. (2005). Small and Medium Enterprises, Glossary of Statistical Terms. Available at: https://stats.oecd.org/glossary/detail.asp?ID=3123 (accessed 13 September 2017).

Parkhe, A. (1993). 'Strategic alliance structuring: A game theoretic and transaction cost examination of interfirm cooperation'. Academy of Management Journal, 36, 794-829.

Podsakoff, P. M., MacKenzie, S. B., Lee, J-Y. and Podsakoff, N. P. (2003). 'Common method biases in behavioral research: A critical review of the literature and recommended remedies'. Journal of Applied Psychology, 88, 879-903.

Provan, K. G. and Skinner, S. J. (1989). 'Interorganizational dependence and control as predictors of opportunism in dealer-supplier relations'. Academy of Management Journal, 32, 202-12.

Ragin, C. C. (2006). 'Set relations in social research: Evaluating their consistency and coverage'. Political Analysis, 14, 291-310.

Ragin, C. C. (2008). Redesigning Social Inquiry: Fuzzy Sets and Beyond. Chicago, IL: University of Chicago Press. 
Reuber, A. R. and Fischer, E. (1997). 'The influence of the management team's international experience on the internationalization behaviors of SMEs'. Journal of International Business Studies, 28, 807-25.

Rokkan, A. I., Heide, J. B. and Wathne, K. H. (2003). 'Specific investments in marketing relationships: Expropriation and bonding effects'. Journal of Marketing Research, 40, 210-24.

Rugman, A. (1986). 'New Theories of the multinational enterprise: An assessment of internalization theory'. Bulletin of Economic Research, 38, 101-18.

Rugman, A. M. and Verbeke, A. (2003). 'Extending the theory of the multinational enterprises: Internalization theory and strategic management perspectives'. Journal of International Business Studies, 34, 125-37.

Rugman, A. M. and Verbeke, A. (2004). 'A perspective on regional and global strategies of multinational enterprises’. Journal of International Business Studies, 35, 3-18.

Rugman, A. M., and Verbeke, A. (2007). 'Liabilities of regional foreignness and the use of firmlevel versus country-level data: A response to Dunning et al. 2007'. Journal of International Business Studies, 38, 200-05.

Rugman, A. M., Verbeke, A. and Nguyen, Q. T. K. (2011). 'Fifty years of international business theory and beyond'. Management International Review, 51, 755-86.

Sambharya, R. B. (1996). 'Foreign experience of top management teams and international diversification strategies of U.S. multinational corporations'. Strategic Management Journal, 17, 739-46.

Schneider, C. Q. and Wagemann, C. (2012). Set-Theoretic Methods for the Social Sciences: A Guide to Qualitative Comparative Analysis (Strategies for Social Inquiry Series). Cambridge, UK: Cambridge University Press. 
SeaRates.com. (2014). Port to port distance calculator. Available at http://www.searates.com/reference/portdistance/ (Accessed January 2014).

Shrader, R. C., Oviatt, B. M. and McDougall, P. P. (2000). 'How new ventures exploit trade-offs among international risk factors: Lessons for the accelerated internationalization of the 21 st century'. Academy of Management Journal, 43, 1227-47.

Stinchcombe, A. L. (1965). 'Organizations and social structure'. Handbook of Organizations, 44, $142-93$.

Stump, R. L. and Heide, J. B. (1996). 'Controlling supplier opportunism in industrial relationships'. Journal of Marketing Research, 33, 431-41.

Styles, C., Patterson, P. G. and Ahmed, F. (2008). 'A relational model of export performance'. Journal of International Business Studies, 39, 880-900.

Taylor, R. N. (1975). 'Age and experience as determinants of managerial information processing and decision making performance'. Academy of Management Journal, 18, 74-81.

Tsang, E. W. K. (2006). 'Behavioral assumptions and theory development: The case of transaction cost economics'. Strategic Management Journal, 27, 999-1011.

Tung, R. L. and Verbeke, A. (2010). 'Beyond Hofstede and GLOBE: Improving the quality of cross-cultural research'. Journal of International Business Studies, 41, 1259-74.

Verbeke, A. (2013). International Business Strategy, $2^{\text {nd }}$ edition. Cambridge, UK: Cambridge University Press.

Verbeke, A., and Ciravegna, L. (2018). 'International entrepreneurship research versus international business research: A false dichotomy?'. Journal of International Business Studies, 49, 387-394. 
Verbeke, A. and Greidanus, N. S. (2009). 'The end of the opportunism vs trust debate: Bounded reliability as a new envelope concept in research on MNE governance'. Journal of International Business Studies, 40, 1471-95.

Verbeke, A. and Kano, L. (2016). 'An internalization theory perspective on the global and regional strategies of multinational enterprises'. Journal of World Business, 51, 83-92.

Verbeke, A. and Yuan, W. (2013). 'The drivers of multinational enterprise subsidiary entrepreneurship in China: A new resource-based view perspective'. Journal of Management Studies, 50, 236-58.

Wathne, K. H. and Heide, J. B. (2000). 'Opportunism in interfirm relationships: Forms, outcomes, and solutions'. Journal of Marketing, 64, 36-51.

Welch, C., Piekkari, R., Plakoyiannaki, E. and Paavilainen-Mäntymäki, E. (2011). 'Theorising from case studies: Towards a pluralist future for international business research'. Journal of International Business Studies, 42, 740-62.

Williamson, O. E. (1985). The Economic Institutions of Capitalism. New York: The Free Press.

Wu, F., Sinkovics, R. R., Cavusgil, S. T. and Roath, A. S. (2007). 'Overcoming export manufacturers' dilemma in international expansion'. Journal of International Business Studies, 38, 283-302.

Zachary, M. A., Gianiodis, P. T., Payne, G. T. and Markman, G. D. (2015). 'Entry timing: Enduring lessons and future directions'. Journal of Management, 41, 1388-1415.

Zahra, S. A., Ireland, R. D. and Hitt, M. A. (2000). International expansion by new venture firms: International diversity, mode of market entry, technological learning, and performance'. Academy of Management Journal, 43, 925-50. 
Zeng, D. Z. (Ed.) (2010). Building Engines for Growth and Competitiveness in China: Experience with Special Economic Zones and Industrial Clusters. Washington, DC: World Bank.

Zhou, K. Z. and Poppo, L. (2010). 'Exchange hazards, relational reliability, and contracts in China: The contingent role of legal enforceability'. Journal of International Business Studies, 41, 861-81.

Zhou, K. Z. and Xu, D. (2012). 'How foreign firms curtail local supplier opportunism in China: Detailed contracts, centralized control, and relational governance'. Journal of International Business Studies, 43, 677-92.

Zhou, L., Wu, W. and Luo, X. (2007). 'Internationalization and the performance of born-global SMEs: The mediating role of social networks'. Journal of International Business Studies, 38, 673-90. 
Table 1. Contextual antecedents of opportunism in foreign market entry in the prior empirical literature

\begin{tabular}{|c|c|c|}
\hline Antecedents & $\begin{array}{l}\text { Empirical studies of opportunism (between brackets, the type of firms } \\
\text { examined and the country of focus, if only one country) }\end{array}$ & Present study \\
\hline $\begin{array}{l}\text { Trust, } \\
\text { commitment, } \\
\text { quality of } \\
\text { relationship }\end{array}$ & $\begin{array}{l}\text { John, } 1984 \text { (Franchises, US); Deeds and Hill, } 1999 \text { (Biotech alliances, US); } \\
\text { Brown et al., } 2000 \text { (Hotel chains, US); Wu et al., } 2007 \text { (Exporters); Heide et } \\
\text { al., } 2007 \text { (Manufacturers-distributors, US); Katsikeas et al., } 2009 \text { (Importers- } \\
\text { exporters); Styles and colleagues, } 2008 \text { (Exporters-importers); Lado et al., }\end{array}$ & $\begin{array}{l}\text { Controlled for: Entries } \\
\text { in new markets using } \\
\text { new distributors = no } \\
\text { prior relationship }\end{array}$ \\
\hline
\end{tabular}
2008 (Producers-distributors); Luo et al., 2009 (Buyers-suppliers, China); Caniëls and Gelderman, 2010 (Information technology, Netherlands); El Akremi et al., 2011 (Franchises, France); Zhou and Xu, 2012 (Importersexporters); Handley and Angst, 2015 (Outsourcing)

Control and monitoring mechanisms

Asset specificity, type of transaction

Distance

Organizational characteristics
John, 1984 (Franchises, US); Parkhe, 1993 (Strategic alliances); Stump and Heide, 1996 (Buyer-supplier, US); Carson et al., 2006 (R\&D partnerships, US); Luo, 2007a (Joint ventures); Luo, 2007b (Joint ventures); Heide et al., 2007 (Manufacturers-distributors, US); Liu et al., 2009 (Manufacturersdistributors, China); Ju et al., 2011 (Exporters-importers); Zhou and Poppo, 2010 (Manufacturers-suppliers, China); Zhou and Xu, 2012 (Importersexporters); Handley and Angst, 2015 (Outsourcing)

Provan and Skinner, 1989 (Equipment dealers, US); Parkhe, 1993 (Strategic alliances); Stump and Heide, 1996 (Buyers-suppliers, US); Rokkan et al., 2003 (Manufacturers-distributors, US); Dickson et al., 2006 (R\&D Alliances); Luo, 2007b (Joint ventures); Liu et al., 2009 (Manufacturers-distributors, China); Ju et al., 2011 (Exporters-importers); Katsikeas et al., 2009 (Importers-exporters)

Katsikeas et al., 2009 (Importers-exporters)

Dickson et al., 2006 (R\&D Alliances); Wu et al., 2007 (Exporters); Katsikeas et al., 2009 (Importers-exporters)
Controlled for: Similar transactions, same entry mode
Controlled for: Similar firms, similar transactions

Measured: Market entry share

Measured: Market distance

Controlled for: Similar firms.

Measured: Young age

Measured: Managerial experience

Measured: Network size

Search performed using 'Opportunism'; 'Opportunism + market entry'; 'Opportunistic'; 'Opportunistic + market entry' on ABI/INFORM, Google Scholar and journals' search engines, focusing on top-ranked Strategy and IB journals. Total of 65 studies found: 42 conceptual, 23 empirical. Table I, updated to 2016, shows the 23 empirical studies measuring opportunism in a real-world empirical context. The third column specifies whether the opportunism antecedents are 'controlled for' ex ante by our research design and sample definition, or whether they are 'measured' by including them as one of the antecedents in the fsQCA model. In parentheses, the type of transaction in which opportunism was measured in each paper. 
Table 2. Descriptive statistics for the antecedents of opportunism examined

\begin{tabular}{lcccrrrr}
\hline Variables & Count & $\begin{array}{c}\text { Missing } \\
\text { count }\end{array}$ & Mean & Median & $\begin{array}{c}\text { Standard } \\
\text { deviation }\end{array}$ & Minimum & Maximum \\
\hline Opportunism & 133 & 0 & 3.82 & 4.17 & 1.28 & 1 & 6.17 \\
Managerial experience & 133 & 0 & 6.85 & 5 & 5.13 & 1 & 33 \\
Market entry share & 126 & 7 & 20.97 & 20 & 15.87 & 2 & 80 \\
Market distance (kms) & 133 & 0 & 6,381 & 6,830 & $3,141.02$ & 82 & 10,586 \\
Young age & 133 & 0 & 4.58 & 3 & 4.96 & 0 & 21 \\
Network size & 129 & 4 & 15.36 & 10 & 20.29 & 3 & 100 \\
\hline
\end{tabular}

Note: The number of foreign market entries per firm in the dataset varies. The dataset has several foreign market entries per firm, but it does not include all foreign market entries performed by the firm during its history.

Table 3. Consistency values of plausible configurations with a minimum threshold of four cases

\begin{tabular}{|c|c|c|c|c|c|c|}
\hline $\begin{array}{l}\text { Managerial } \\
\text { experience }\end{array}$ & $\begin{array}{c}\text { Market } \\
\text { entry } \\
\text { share }\end{array}$ & $\begin{array}{l}\text { Market } \\
\text { distance }\end{array}$ & $\begin{array}{l}\text { Young } \\
\text { age }\end{array}$ & $\begin{array}{l}\text { Network } \\
\text { size }\end{array}$ & $\begin{array}{l}\text { Number of cases with } \\
\text { membership greater } \\
\text { than } 0.5 \text { in this plausible } \\
\text { combination of } \\
\text { antecedents }\end{array}$ & Raw consistency \\
\hline 0 & 0 & 0 & 1 & 0 & 5 & 0.962 \\
\hline 1 & 1 & 0 & 1 & 0 & 6 & 0.943 \\
\hline 0 & 1 & 1 & 1 & 1 & 7 & 0.925 \\
\hline 0 & 1 & 0 & 1 & 0 & 6 & 0.922 \\
\hline 1 & 0 & 1 & 0 & 0 & 7 & 0.9 \\
\hline 1 & 1 & 1 & 0 & 1 & 6 & 0.889 \\
\hline 0 & 0 & 1 & 1 & 1 & 9 & 0.881 \\
\hline 1 & 0 & 1 & 0 & 1 & 5 & 0.876 \\
\hline 0 & 0 & 1 & 1 & 0 & 4 & 0.876 \\
\hline 0 & 1 & 1 & 1 & 0 & 4 & 0.875 \\
\hline 1 & 0 & 1 & 1 & 0 & 5 & 0.815 \\
\hline 1 & 0 & 1 & 1 & 1 & 16 & 0.813 \\
\hline 1 & 1 & 1 & 1 & 0 & 5 & 0.81 \\
\hline \multirow[t]{2}{*}{1} & 1 & 1 & 1 & 1 & 16 & 0.789 \\
\hline & & & & TOTAL & 101 & \\
\hline
\end{tabular}


Table 4. Configurations linked to importers' opportunism in new foreign market entry

\begin{tabular}{lccccc}
\hline Antecedent & \multicolumn{5}{c}{ Configuration number } \\
\hline & $\mathbf{1}$ & $\mathbf{2}$ & $\mathbf{3}$ & $\mathbf{4}$ & $\mathbf{5}$ \\
\hline Managerial experience & $\otimes$ & $\otimes$ & $\square$ & $\bullet$ & $\bullet$ \\
Market entry share & $\square$ & $\square$ & $\bullet$ & $\otimes$ & $\square$ \\
Market distance & $\square$ & $\bullet$ & $\otimes$ & $\bullet$ & $\bullet$ \\
Young age & $\bullet$ & $\bullet$ & $\bullet$ & $\otimes$ & $\otimes$ \\
Network size & $\otimes$ & $\square$ & $\otimes$ & $\square$ & $\bullet$ \\
\hline Raw coverage & 0.43 & 0.44 & 0.26 & 0.35 & 0.31 \\
Unique coverage & 0.05 & 0.06 & 0.02 & 0.04 & 0.02 \\
Consistency & 0.84 & 0.83 & 0.91 & 0.88 & 0.86 \\
Solution coverage: 0.69 & & & & & \\
Solution consistency: 0.81 & & & & & \\
\hline
\end{tabular}

$\otimes=$ Absence of an antecedent; $\bullet=$ Presence of an antecedent; $\square=$ The presence or absence of the antecedent does not affect whether opportunism occurs.

Each column represents a combination of antecedents, or a configuration, leading to the outcome 'opportunism in the market entry'. Configuration 1 represents a market entry performed by a young firm lacking managerial experience or a large network (market share in total exports and distance not relevant to opportunism). Configuration 2 represents a market entry by a young firm that lacks managerial experience and enters a distant market (market share in total exports and network size not relevant to opportunism). Configuration 3 represents an entry by a young firm into a non-distant market, with a large market share in total exports (managerial experience not relevant to opportunism). Configuration 4 represents the entry by an older firm with managerial experience into a distant market, with a small market share in total exports (network size not relevant to opportunism). Configuration 5 represents the entry by an older firm with managerial experience and a large network, entering a distant market (market entry share not relevant for opportunism). 
Figure 1. Conceptual model

\section{Contextual antecedents and a priori expected effects}

Parameters controlled for by study design: constant/homogenous factors within the constructed sample
1) Managerial experience (-)

2) Market entry share $(+)$

3) Market distance $(+)$

4) Young age $(+)$

5) Network size (-)
Opportunism in new foreign market entry

1) Trust, commitment, quality of relationship (controlled for: No prior relationship)

2) Control and monitoring mechanisms (controlled for: Similar transactions, same entry mode)

3) Asset specificity, type of transaction (controlled for: Similar firms, similar transactions)

4) Organizational resources (controlled for: Similar firms)

The conceptual model represents the contextual antecedents of opportunism by importers in the new foreign market entries of exporters. The model is based on the literature search reported in Table 1. The signs (+) and (-) represent the expected effects, i.e. whether, according to the extant literature, the antecedent is expected to be associated with opportunism (+) or to be preventing opportunism (-). For example, market distance (+), is expected to be linked to opportunism by importers in new foreign market entry. 
Figure 2. Configurations of opportunism in new foreign market entry

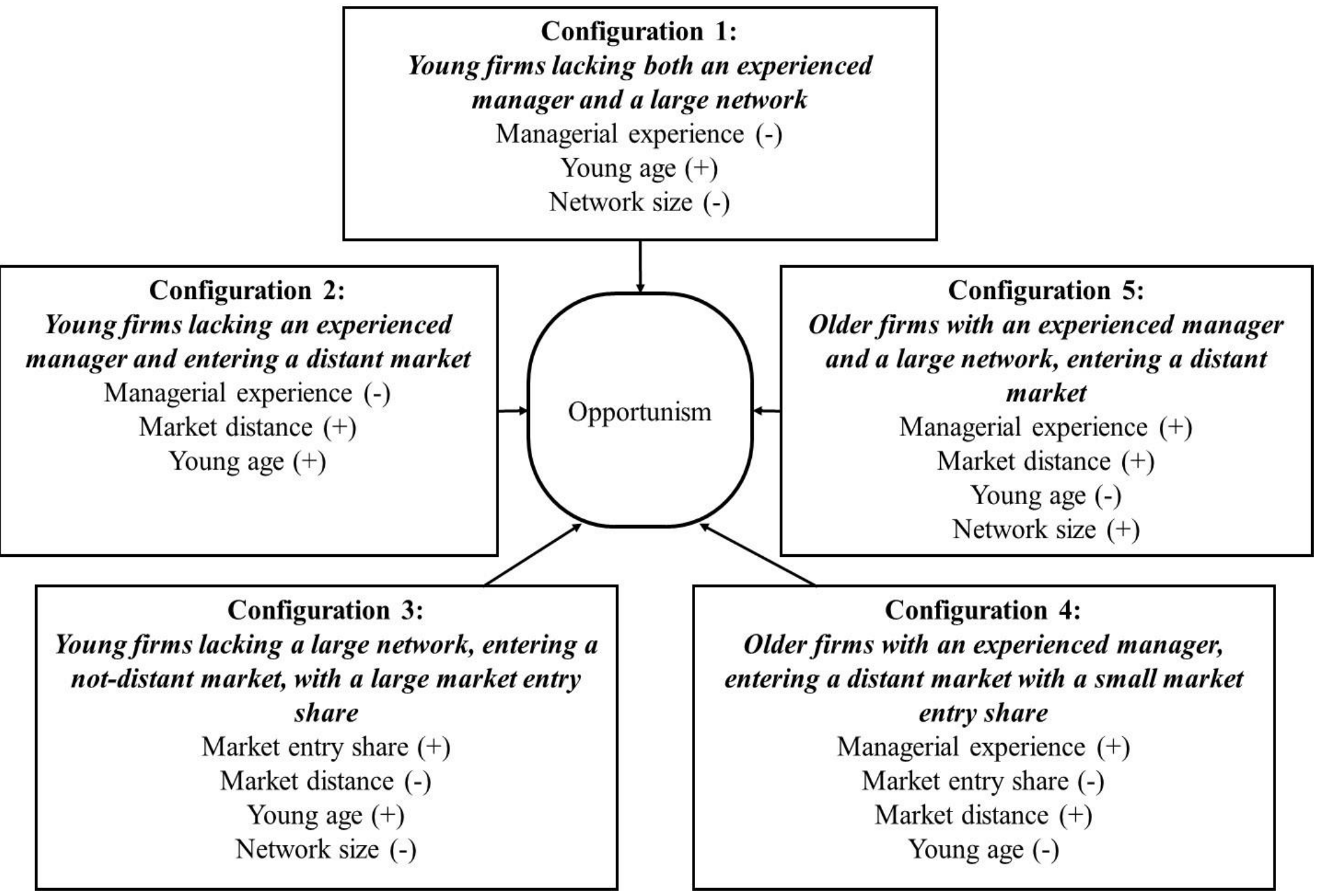

The configurations represent the five combinations of antecedents equifinally linked to importers' opportunism in new foreign market entry. The signs (+) and (-) denote how each antecedent appears in each configuration that in our sample was linked to the occurrence of opportunism. For example, Configuration 1 depicts firms that do not have an experienced manager [Managerial experience (-)]; are young [Young age (+)]; and lack a large network size [Network size (-)]. Antecedents that do not have any effect on opportunism in that specific configuration, do not appear in the box representing such configuration. For example, in Configuration 2, market entry share is not relevant, and thus is not depicted in the box representing that configuration - Configuration 2 entails that a young firm entering a distant market without an experienced manager may suffer from opportunistic behaviour by importers disregarding of whether the market entry share is large or small. 


\section{NOTES}

${ }^{1}$ We are grateful to Gideon Markman, Guest Editor of the JMS Special Issue and to three anonymous reviewers for their insightful suggestions. We would also like to express our thanks to Zhan Ge for his support of the data collection, and for his contribution to our understanding of the Chinese local context. We also owe a debt of gratitude to Liena Kano, for chairing a session at the AIB Conference in Vancouver where an early version of this paper was presented, and to Julian Birkinshaw for his support of this project.

${ }^{2}$ The firms entered 41 different markets: (in parentheses the number of market entries per country): Albania (1), Argentina (3), Australia (3), Austria (1), Bangladesh (3), Belgium (1), Bolivia (1), Brazil (6), Cambodia (1), Canada (2), Denmark (1), Egypt (2), France (12), Germany (10), Hong Kong (1), India (6), Iran (2), Italy (9), Japan (7), Kuwait (1), Lesotho (1), Malaysia (2), Netherlands (1), New Zealand (1), Oman (1), Paraguay (1), Philippines (2), Russia (3), Saudi Arabia (2), South Korea (6), Spain (3), Sweden (1), Taiwan (1), Thailand (2), Turkey (3), UAE (2), UK (8), US (17), Uruguay (1), Venezuela (1), Vietnam (1).

${ }^{3}$ We use the term 'outcome' instead of dependent variable and 'antecedents' instead of independent variables, following established practice in fsQCA (Fiss et al., 2013; Ragin, 2006).

${ }^{4}$ Our search, which was updated in 2016, included the following journals: Academy of Management Journal, Academy of Management Perspectives, Academy of Management Review, Entrepreneurship Theory and Practice, Global Strategy Journal, Journal of Business Venturing, Journal of International Business Studies, Journal of International Management, Journal of Management Studies, Journal of World Business, British Journal of Management, Strategic Management Journal, Journal of Management, Organization Science, Organization Studies, Journal of Marketing, and Journal of Marketing Research. We excluded Jap and colleagues (2013) because it studies opportunism in a sample of students rather than in a real business context.

${ }^{5}$ We do not disclose the actual names of the CEO and company because of privacy concerns.

${ }^{6}$ Larger firms typically use multiple entry modes, thereby reflecting a formal, ex ante evaluation to determine which entry mode is the most efficient under particular circumstances. Such firms typically also have teams of managers working on export sales contracts so that it becomes more uncertain whether the researcher is surveying the relevant decision maker. ${ }^{7}$ Instrument used to measure opportunism, based on John (1984). Questions asked: (a) The buyer has always provided us a completely truthful picture of his business; (b) Complete honesty does not pay when dealing with this buyer; (c) Sometimes this buyer alters the facts slightly in order to get what he needs; (d) The buyer carries out his duties even if we do not check up on him; (e) This buyer has sometimes promised to do things without actually doing them later; (f) The buyer seems to feel that it is OK to do anything within his means that will help further his firm's interests.

${ }^{8}$ We do not disclose the actual names of the CEO and company because of privacy concerns.

${ }^{9}$ We do not disclose the actual names of the CEO and company because of privacy concerns.

${ }^{10}$ Given a fixed level of asset specificity, a variety of contextual elements, e.g., in the institutional, economic and technological spheres, can increase or reduce the likelihood of opportunism. The challenge for future research is to determine when some of these contextual elements may actually 'take over' from asset specificity, so as to determine both the likelihood of opportunism materializing, and the safeguards needed to prevent it from occurring, or to mitigate its 
effects. In our view, the presence of managerial experience with a particular type of contracting and the systematic exercise of due diligence (meaning the absence of both negligence and hubris) as described in some of our scenarios with configurations of opportunism antecedents, may make the level of asset specificity just one, among many, parameters likely to be associated with opportunism and other expressions of unreliability. 